\title{
A rare case of Crigler-Najjar syndrome type II with pregnancy
}

\author{
Rachna Chaudhary $^{1}$, Amit Maheshwari ${ }^{2}$, Deepmala $^{1}$, Virendra Tapparwal ${ }^{3}$
}

\author{
${ }^{1}$ Department of Obstetrics \& Gynecology, ${ }^{2}$ Department of Medicine, ${ }^{3}$ Department of Pathology, LLRM Medical \\ College, Meerut, UP, India
}

Received: 30 December 2013

Accepted: 02 February 2014

\author{
*Correspondence: \\ Dr. Rachna Chaudhary, \\ E-mail: drrachnachaudhary@gmail.com
}

(C) 2014 Chaudhary R et al. This is an open-access article distributed under the terms of the Creative Commons Attribution Non-Commercial License, which permits unrestricted non-commercial use, distribution, and reproduction in any medium, provided the original work is properly cited.

\begin{abstract}
Crigler-Najjar syndrome (CNS) has been rarely described during pregnancy with only few case reports available in literature, CNS is expressed in two forms, CNS type I and CNS type II; Type I CNS results in severe unconjugated hyperbilirubinemia and neurological impairment in newborn and is fatal. Type II CNS results in milder unconjugated hyperbilirubinemia responding to Phenobarbital treatment with better outcome.
\end{abstract}

Keywords: Pregnancy, Hyperbilirubinemia

\section{INTRODUCTION}

CNS is a rare autosomal recessive disorder of bilirubin metabolism, caused by mutation of bilirubin uridine glucoronosyltransferase gene (UGT1A 1) resulting in either complete deficiency of UGT enzyme (CNS type-I) or decreased activity of UGT. Incidence is less than 1 case per 1 million births, only a few hundred cases have been described, including 9 cases of pregnancy with CNS, exact prevalence is not known.

Pregnancy in CNS is a therapeutic challenge, due to the risk of bilirubin encephalopathy with serious neurological impairment as life threatening complication for the fetus.

\section{CASE REPORT}

A 25 year old, Muslim, lady of Indian origin belonging to low socio-economic status presented in gynecology emergency with labour pains. She was primipara with 38 weeks of pregnancy with affliction of polio in right leg along with deep jaundice. Patient had history of exploratory laparotomy for appendicitis 4 years ago; patient also had a spontaneous abortion of 3 months before dilatation \& evacuation 2 years ago. Her parents gave $\mathrm{H} / \mathrm{o}$ Jaundice since her childhood with $\mathrm{h} / \mathrm{o}$ poor weight gain, on \& off fever for which they did not consult any physician. Her family history was also not significant she had no old medical records, investigations pertaining to her medical problem. She was an unbooked case with no previous antenatal visits.

On general examination Pt was fair, thin built, pale, poorly nourished with yellow discoloration of sclera with slight yellow staining of palm \& soles. Obstetrical examination revealed a singleton pregnancy of term size with cephalic presentation with regular fetal heart sounds.

Her laboratory investigations revealed, a complete normal haemogram with hemoglobin of $9.5 \mathrm{~g} \%$, blood group ' $\mathrm{O}$ ' positive, her total serum bilirubin was 10.9 $\mathrm{mg} / \mathrm{dl}$ with unconjugated bilirubin $9.7 \mathrm{mg} / \mathrm{dl} \quad$ \& conjugated bilirubin $1.2 \mathrm{mg} / \mathrm{dl}$, her liver enzymes were within normal limit with normal total serum proteins, viral titers were negative for hepatitis B \& $\mathrm{C}$ virus excluding hepatitis, HIV I/II infection were negative, Antenatal scan was performed which documented a single live intrauterine fetus corresponding to date with adequate liquor, with normal placenta \& no congenital anomaly was detected. Upper abdomen scan was of normal study with no organomegaly. 
Because of the cost of genomic analysis for $\mathrm{UGT}_{1} \mathrm{~A}_{1}$ gene it was not performed.

A caesarean section was performed for contracted pelvis, she gave birth to healthy female baby of wt $2.7 \mathrm{~kg}$ with baby length $51 \mathrm{~cm}$ with APGAR score 5, 6, 7, 9 at 1, 5, $10,15 \mathrm{~min}$ and baby was shifted to neonatal intensive care unit for observation.

Newborn had mild hyperbilirubinemia, which did not require any treatment and resolved on its own. Post operative period of patient was uneventful.

Her repeat liver function test after 7 days revealed total serum bilirubin of $8.9 \mathrm{mg} / \mathrm{dl}$ with unconjugated bilirubin $3.2 \mathrm{mg} / \mathrm{dl}$ and conjugated bilirubin of $5.7 \mathrm{mg} / \mathrm{dl}$, she was hence diagnosed as CNS type-II by physician and was transferred under their care for close follow up. A repeat LFT again after 7 days was almost same, patient was then discharge.

\section{DISCUSSION}

CNS type II pregnancy is extremely rare but important clinical entity to recognize, because adverse fetal outcome may result if bilirubin level is not adequately controlled. After reviewing much literature by different authors we realized that pregnancy is not contraindicated in CNS type II and good results are seen with use of phenobarbitone during pregnancy. Follow up of newborn is required for growth, development $\&$ hearing functions.
Funding: No funding sources

Conflict of interest: None declared

Ethical approval: Not required

\section{REFERENCES}

1. Passuello V, Puhl AG, Wirth S, Steiner E, Skala C, Koelbl H, Kohlschmidt N. Pregnancy outcome in maternal Crigler-Najjar syndrome type II: a case report and systematic review of the literature. Fetal Diagn Ther. 2009;26(3):121-6.

2. Arora N, Chaudhary S. Pregnancy with CriglerNajjar syndrome type-II, J Obstet Gynecol 2009;29:242-4.

3. Holstein A, Plaschke A, Lohse P, Egberts EH. Successful Photo and Phenobarbital therapy during pregnancy in a woman with Crigler-Najjar syndrome type-II. Scand J Gasgroenterol 2005;40:1124-6.

4. Smith JF, Baker JM. Crigler-Najjar disease in pregnancy. Obstet Gynecol 1194;84:670-2.

5. Shakuntala PN, Poornima M, Padmalatha VV, Rao SR. Successful pregnancy outcome in maternal Crigler-Najjar syndrome type-II. Online J Health Allied Scs 2012;11(3):12.

DOI: $10.5455 / 2320-1770 . i j \operatorname{rog} 20140356$

Cite this article as: Chaudhary R, Maheshwari A, Deepmala, Tapparwal V. A rare case of CriglerNajjar syndrome type II with pregnancy. Int J Reprod Contracept Obstet Gynecol 2014;3:261-2. 